\title{
PRINSIP-PRINSIP KEPEMIMPINAN YUSUF \\ DALAM MENGHADAPI PERUBAHAN BERDASARKAN KITAB KEJADIAN 37-50
}

\author{
Dedy Riswanto \\ Jermia Djadi \\ sttjaffray@yahoo.com
}

\section{PENDAHULUAN}

\section{Latar Belakang Masalah}

Perubahan adalah suatu hal yang tidak dapat dibendung dan dihalangi oleh siapa pun, karena perubahan adalah hal mutlak yang terjadi secara alamiah. Perubahan akan terus terjadi dalam segala bidang, baik dalam politik, ekonomi, sosial, budaya, dan dalam megatrand lainnya. Inilah sebuah hukum alam yang berlaku konstan bagi semua makhluk yang hidup di atas bumi ini.

Tak terkecuali bagi gereja, perubahan merupakan fakta yang selalu menjadi sahabat sekaligus musuh besar yang terkadang mematikan fungsi gereja dalam menjalankan tugas misionernya di dunia ini. Disebut sahabat bila gereja mampu mengendalikan perubahan dan mendulang banyak keuntungan positif yang dibawa oleh perubahan itu. Sebaliknya, perubahan akan menjadi musuh besar bila gereja tidak siap menghadapi perubahan dan membiarkan diri digilas oleh perubahan itu.

Dalam zaman yang serba moderen ini ada banyak sisi kehidupan yang dipaksa untuk berubah, sehingga pemimpin gereja harus mampu membacanya dan membenahi diri untuk memanfaatkan perubahan itu. Bila tidak, maka pelayanan akan hancur. Eka Darmaputra mengungkapkan, "Pemimpin sejati adalah pemimpin yang menjadi pengendali, pendorong, penggerak dan pengubah." Dengan demikian seorang pemimpin akan menjadi penentu keberhasilan di mana dirinya memimpin. Kalau seorang pemimpin tidak membawa dampak apa pun terhadap yang dipimpin, maka dia bukanlah pemimpin. Bila datang perubahan, maka pelayanannya akan gagal. Karena dia tidak bisa menjadi pengendali perubahan, melainkan dirinya yang digilas oleh perubahan itu. Eka Darmaputra juga mengatakan, "Pemimpin yang bijak akan tahu apa yang baik dan harus ia pertahankan; apa yang kurang dan harus ia tingkatkan; apa yang salah dan perlu ia koreksi; dan mana yang menuntut inovasi-inovasi serta terobosan-terobosan baru." ${ }^{2}$

Fenomena melemahnya pelayanan gereja akibat tergilas oleh perubahan zaman tak sedikit melanda gereja-gereja besar saat ini. Selain karena tidak mampu menghadapi pengaruh globalisasi, di antara gereja pun telah timbul persaingan dalam mengemas pelayanan untuk menjangkau sesama jemaatnya. Pelayanan gereja yang dianggap "kontemporer" akan menjadi primadona dan akan dihadiri oleh ribuan jemaat yang berasal dari gereja lain dalam setiap kali ibadah. Inilah salah satu fakta perubahan yang banyak mengancam eksistensi gereja pada masa kini.

Bill Gates, seorang CEO Microsoft mengatakan, "Berubah atau diubah bukan pilihan, perubahan harus dimanfaatkan untuk diterima daripada menunggu perubahan memanfaatkan kita." ${ }^{3}$ Suatu latar berlakang munculnya perspektif itu ditandai dengan empat megatrend yang berubah, yaitu meluasnya informasi, dunia hiburan yang meledak dengan segala macam variasinya, produk dan brand ditawarkan secara variatif, serta alat teknologi semakin canggih dan dijangkau dengan harga murah. Jadi, gereja yang tidak sigap dengan kenyataan ini, maka akan ketinggalan atau ditinggalkan.

Dengan melihat masalah ini, maka penulis tertarik untuk mengkaji ulang prinsip yang terdapat dalam Firman Allah, bagaimana seorang pemimpin yang berhasil

\footnotetext{
${ }^{\text {l} E k a ~ D a r m a p u t r a, ~ K e p e m i m p i n a n ~ d a l a m ~ P e r s e f e k t i f ~ A l k i t a b ~(Y o g y a k a r t a: ~ K a i r o s, ~ 2005), ~} 15$.

${ }^{2}$ Ibid, 17

${ }^{3}$ Bill Gates dalam Parel T.J, “Gilasan Sebuah Perubahan," Inspiration Ministry diakses 15 Februari 2019; tersedia di htt:///www.Artikel/gilasan-sebuah-perubahan.html.
} 
mengendalikan perubahan. Alkitab mengisahkan seorang pemimpin di Mesir yang bernama Yusuf dalam Kejadian 37-50. Ia adalah seorang pemimpin yang berhasil menghadapi krisis pangan yang melanda seluruh Mesir hingga merambah ke tanah Kanaan. Kelaparan yang mengubah situasi kehidupan manusia pada waktu itu banyak menimbulkan kemiskinan yang cukup parah bagi mereka yang tidak siap menghadapi perubahan. Tetapi, Yusuf adalah pemimpin yang mampu mengendalikan perubahan sehingga keluarganya dan seluruh istana Firaun diselamatkan dari depresi besar yang terjadi selama tujuh tahun itu.

Penulis memandang bahwa prinsip-prinsip kepemimpinan yang dilakukan Yusuf patut menjadi salah satu solusi bagi gereja dalam menghadapi perubahan saat ini, apalagi dalam mengatasi krisis global saat ini. Maka dari itu, penulis sangat tertarik untuk meneliti kembali prinsip-prinsip yang dilakukan oleh Yusuf dan ingin menulisnya dalam sebuah karya ilmiah yang berjudul: "PRINSIP-PRINSIP KEPEMIMPINAN YUSUF DALAM MENGHADAPI PERUBAHAN BERDASARKAN KITAB KEJADIAN 37-50"

\section{Pokok Masalah}

Berdasarkan latar belakang masalah di atas, maka pembahasan ini berfokus kepada prinsip menghadapi perubahan, artinya setiap perubahan hanya dapat prinsip-prinsip khusus. Oleh karena itu, masalah yang akan diteliti adalah:

Pertama, Apa prinsip-prinsip, kepemimpinan Yusuf dalam menghadapi perubahan?

Kedua, Bagaimana pemimpin gereja mengimplementasikan prinsip-prinsip ini secara relevan dalam menghadapi perubahan?

\section{Tujuan Penulisan}

Dalam penulisan ini, ada beberapa hal penting yang perlu diperhatikan dan menjadi tujuan dalam penulisan ini:

Pertama, Untuk menemukan prinsip-prinsip kepemimpinan Yusuf dalam menghadapi perubahan.

Kedua, Untuk mengiplementasikan prinsip-prinsip kepemimpinan Yusuf secara relevan, sehingga dapat dijadikan pedoman bagi seorang pemimpin Kristen, sehingga ia mampu menjadi pengendali perubahan.

\section{Batasan Penulisan}

Karya ilmiah ini hanya membahas prinsip-prinsip kepemimpinan Yusuf dalam menghadapi kelaparan di Mesir dalam Kitab Kejadian pasal 37-4l, dalam pengertian penulis hanya membatasi pada prinsip-prinsip kepemimpinan yang digunakan oleh Yusuf dalam menghadapi kelaparan di Mesir, sehingga dia mampu menjadi pemimpin yang mengendalikan perubahan. Semua prinsip ini akan menolong para pemimpin gereja untuk diimplementasikan secara relevan dalam menjawab perubahan. 


\section{METODOLOGI PENELITIAN}

Dalam bagian ini penulis menggunakan metodologi penelitian kualitatif, tentang mencari prinsip-prinsip kepemimpinan Yusuf pada masa lalu dan menjadikannya relevan pada masa kini. Winarno Surakhmad mengatakan, "Metode merupakan cara utama yang dipergunakan untuk mencapai tujuan.." Jadi, metode digunakan untuk mencapai tujuan yang sudah ditentukan.

\section{Materi dan Sumber Penelitian}

Materi dan sumber penelitian yang dipakai penulis dalam penulisan ini terdiri atas beberapa sumber, yaitu Alkitab, literatur tentang kepemimpinan, literatur tentang perubahan, literatur tentang tokoh, tafsiran Alkitab dan bahan internet.

\section{Teknik Pengumpulan Data}

Adapun teknik pengumpulan dalam penulisan karya ilmiah ini menggunakan beberapa teknik sebagai berikut,

\section{Inventarisasi}

Anton Bakker dan Achmad Charri Zubair mengatakan, "Iventarisasi ialah mempelajari karya tokoh itu sendiri, agar dapat diuraikan dengan setepat dan sejelas mungkin. Mengumpulkan juga bahan yang tersebar dalam kepustakaan mengenai tokoh filsafat dan karya-karyanya." 5 Dengan demikian penulis meneliti apa yang menjadi karya dan filsafat dari Yusuf serta mempelajari tentang kehidupannya.

\section{Evaluasi Kritis}

Anton Bakker dan Achmad Charri Zubair menjelaskan, "Evaluasi kritis merupakan studi lansung mengenai pemikiran tokoh. Peneliti membuat perbandingan antara uraianuraian ahli mengenai tokoh itu." Jadi, valuasi kritis merupakan cara teknik pengumpulan data yang berusaha membuat perbandingan melalui pemikiran tokoh yang sedang diteliti dan pemikiran para ahli sehingga terjadi sinkronisasi.

\section{Kritik Historis dan Naratif}

Sumadi Suryabrata mengatakan, "Penelitian historis adalah membuat rekontruksi masa lampau secara sistematis dan objektif, dengan cara mengumpulkan, mengevaluasi, memverifikasikan, serta mensistesiskan bukti-bukti untuk menegakkan fakta dan memperoleh kesimpulan yang kuat." Jadi, penelitian historis merupakan teknik pengumpulan data yang digunakan dalam penelitian kualitatif untuk menjadikan prinsip masa lampau relevan pada masa kini.

Dengan demikian, peneliti mencoba melakukan penelitian historis terhadap tokoh yang bersangkutan. Winarno Surakhmad menjelaskan, "Penyelidikan yang menggunakan metode historis adalah penyelidikan yang mengaplikasikan metode pemecahan yang ilmiah dari persepektif historis suatu masalah."' Senada dengan itu, Andreas B. Subagyo mengatakan, "Kritik naratif ialah analisis kitab-kitab di Alkitab atau bagian-bagiannya sebagai sebuah kesusastraan yang utuh dengan memusatkan perhatian pada tokoh, alur, latar belakang, dan sudut pandang." Jadi, penelitian kritik naratif adalah penelitian yang bersifat analisis terhadap objek penelitian.

\footnotetext{
${ }^{4}$ Winarno Surakhmad, Penelitian Ilmiah: Dasar Penelitian Ilmiah (Bandung: Tarsito,1982), 131.

${ }^{5}$ Anton Bakker dan Achmad Charri Zubair, Metode Penelitian Filsafat (Yogyakarta: Kanasius, 1990),

${ }^{6}$ Ibid.

${ }^{7}$ Sumadi Sur yabrata, Metodologi Penelitian (Jakarta: Rajawali Pers, 1991), 16.

${ }^{8}$ Winarno Surakhman, Penelitian Ilmiah: Dasar Penelitian Ilmiah (Bandung: Tarsito, 1982), 131.

${ }_{9}^{9}$ Andreas B. Subagyo, Pengantar Riset Kuantitatifdan Kualitatif (Bandung: Kalam Hidup, 2004), 132,
} 


\section{Pemahaman Baru}

Anton Bakker dan Achmad Charri Zubair mengatakan, "Pemahaman baru berarti bertitik tolak dari segala perbedaan pendapat di antara para ahli, dan evaluasi kritis terhadap mereka, dan setelah meneliti kembali dengan saksama karya tokoh yang sedang diteliti, membuat suatu dobrakan pemikiran." ${ }^{.10}$ Dengan demikian, dapat ditemukan bahan baru, atau dibuat pendekatan baru, yang membawa ke suatu pemahaman serba baru, yang berisi lebih dari hanya sintesis semua bahan yang tersedia dan yang mengatasi semua pemecahan sampai sekarang.

\section{Teknik Analisis Data}

\section{Holistika}

Dalam karya ilmiah ini penulis menggunakan teknik analisis data sebagai berikut,

Anton Bakker dan Achmad Charri Zubair mengatakan, "Holistika ialah untuk memahami konsep-konsep filosofis tokoh yang sedang diteliti. Dengan betul-betul, mereka dilihat dalam rangka keseluruhan visinya mengenai manusia dan Tuhan." Jadi, teknik analisa data holistika merupakan penelitian yang mencakup keseluruhan dari kehidupan seorang tokoh yang sedang diteliti.

\section{Kesinambungan Historis}

Anton Bakker dan Achmad Charri Zubair mengatakan, "Kesinambungan historis ialah dilihat dari benang merah dalam pengembangan pikiran tokoh yang berhubungan dengan lingkungan historis dan pengaruh yang dialaminya maupun dalam perjalanan hidupnya sendiri. Lebih luas daripada konteks pemikiran tokoh zaman dulu diterjemahkan dalam terminologi sesuai dengan cara berpikir aktual sekarang."12 Jadi, teknik ini melihat dari konteks pada zaman tokoh yang sedang diteliti dan mengambil pemikirannya untuk diterapkan dalam konteks sekarang.

\section{PRINSIP-PRINSIP KEPEMIMPINAN YUSUF}

\section{Prinsip-Prinsip Kepemimpinan Yusuf Dalam Menghadapi Perubahan}

Dalam bagian ini penulis akan menguraikan apa yang menjadi prinsip-prinsip kepemimpinan Yusuf dalam menghadapi perubahan, sehingga dia berhasil dalam kepemimpinannya di tanah Mesir dan menjadi tokoh pengendali perubahan.

\section{Berpegang Teguh Pada Visi}

Kejadian 37:5-11, menceritakan tentang mimpi Yusuf. Dalam mimpi tersebut diceritakan bahwa Yusuf dengan saudara-saudaranya sedang mengikat berkas gandum, kemudian berkas gandum milik Yusuf bangkit tegak berdiri dan berkas saudaranya datang dan sujud menyembah kepada berkas Yusuf. Lalu Yusuf bermimpi lagi untuk yang kedua kalinya, di mana tampak matahari, bulan dan bintang sujud menyembah kepada Yusuf. Arti dari mimpi Yusuf ialah mengambarkan bahwa Yusuf akan menjadi pemimpin besar di mana saudara-saudaranya dan kedua orang tuanya pun akan sujud menyembah kepadanya.

Kejadian 42:6 mengatakan, "Sementara itu Yusuf telah menjadi mangkubumi di negeri itu; dialah yang menjual gandum kepada seluruh rakyat negeri itu. Jadi, ketika saudara-saudara Yusuf datang, kepadanyalah mereka menghadap dan sujud dengan mukanya sampai ke tanah." Ayat ini menjelaskan bahwa Yusuf menjadi penguasa tertinggi kedua setalah Firaun, di mana semua orang dan saudara-saudaranya juga sujud menyembah dengan mukanya sampai ke tanah. Hal ini merupakan realisasi dari mimpi Yusuf pada masa remajanya.

\footnotetext{
${ }^{10}$ Ibid, 62, 63.

${ }^{11}$ Anton Bakker dan Achmad Charri Zubair, Metode Penelitian Filsafat (Yogyakarta: Kanasius, 1990), ${ }^{12}$ Ibid.
} 64. 
Dalam bagian ini penulis akan menguraikan dua kriteria tentang visi yang benar dalam kepemimpnan Kristen, di mana dua hal tersebut akan membedakan visi pemimpin Kristen dan visi pemimpin sekuler. Visi Yusuf adalah visi pemimpin yang benar, karena visinya mencakup dua kriteria tersebut antara lain,

\section{Visi Berasal dari Tuhan}

Kejadian 39:2 mengatakan, "Tetapi TUHAN menyertai Yusuf, sehingga ia menjadi seorang yang selalu berhasil dalam pekerjaannya; maka tinggallah ia di rumah tuannya, orang Mesir itu." Ayat ini mengindikasikan bahwa Yusuf diberkati oleh Tuhan, di mana semua yang dikerjakannya selalu berhasil. Tuhan memberkati Yusuf karena visi Yusuf pada masa remajanya, visi berasal dari Tuhan. Dengan, demikian Allah selalu memberkati Yusuf sehingga dia bisa mencapai visinya.

Visi dari Tuhan tidak pernah gagal, karena Tuhan sendiri akan menolong pemimpin tersebut untuk mencapainya. Visi dari Tuhan selalu jelas, sehingga pemimpin yang menjalaninya tetap fokus kepada visi tersebut. George Barna mengatakan, "Visi adalah suatu gambaran mental yang jelas mengenai masa depan yang lebih baik yang ditanamkan oleh Allah kepada hamba-Nya dan didasarkan pada pemahaman yang akurat tentang Allah, diri sendiri dan situasi yang ada."13 Jadi, visi merupakan gambaran yang jelas tentang masa depan seseorang yang diberikan oleh Allah.

Hal senada juga diungkapkan oleh Bill Hybels, yang mengatakan, "Visi adalah gambaran masa depan yang menimbulkan kegairahan."14 Dengan memiliki visi, seorang pemimpin akan memunyai motivasi untuk mencapai suatu masa depan, yang penuh keberhasilan. Yusuf adalah seorang pemimpin yang memiliki visi yang jelas. Berdasarkan visi yang dimilikinya, Yusuf menjalani kehidupannya dengan keteguhan hati. Yusuf tahu bahwa visinya dari Tuhan, hal itulah yang membuat dia berpegang teguh pada visi tersebut.

Visi yang dimiliki Yusuf sangat kuat, hal itulah yang terus menjadi kekuatan bagi dia untuk menjalani kehidupan yang begitu berat dan mampu bertahan sampai menjadi seorang tokoh pemimpin yang sangat popular di tanah Mesir. Bill Hybels mengatakan, "Rengutlah visi dari seorang pemimpin, maka berarti Anda membunuhnya. Visi adalah bahan bakar yang membuat para pemimpin bertahan." Visi Yusuf berasal dari Allah, sehingga tidak ada yang dapat merengutnya bahkan Alkitab mencatat bahwa Yusuf disertai Tuhan, sehingga semua yang dikerjakannya berhasil (Kejadian 39:3,5,21, 23; 41:16, 38-39, 42:18).

\section{Visi Disertai Dengan Karakter yang Baik}

Seorang pemimpin Kristen tidak cukup hanya memiliki visi dan berpegang teguh pada visi itu, tetapi kriteria visi yang benar selain berasal dari Allah selalu disertai dengan karakter yang baik dari pemimpin tersebut. Kejadian 39:7-20, menceritakan kisah kehidupan Yusuf di rumah Potifar di mana dia digoda oleh istri Potifar untuk melakukan dosa perzinahan. Kejadian 39:9b mengatakan, "Bagaimanakah mungkin aku melakukan kejahatan yang besar ini dan berbuat dosa terhadap Allah?"

Ayat ini menjelaskan bagaimana seorang pemimpin, seperti Yusuf adalah pemimpin yang berkarakter baik, di mana dia tidak mengorbankan visinya hanya untuk melakukan dosa perzinahan dengan istri Potifar. Lalu Kejadian 40:23 menjelaskan bahwa Yusuf tidak diingat oleh juru minum raja yang pernah berjanji kepadanya apabila arti mimpi yang disingkapkan oleh Yusuf benar, maka dia akan mengeluarkan Yusuf dari penjara. Tetapi apa yang terjadi, juru minum tidak lagi mengingatnya. Yusuf sebagai pemimpin yang berkarakter baik tidak sakit hati kepada orang ini.

\footnotetext{
${ }^{13}$ George Barna, the Power of Vision (Jakarta: Metanoia Publishing,1992), 24.

${ }_{15}^{14}$ Bill Hybels, Kepemimpinan Yang Berani (Batam: Gospel Press, 2004), 34.

${ }^{15}$ Ibid, 33.
} 
Kejadian 50:20-21 mengatakan, "Memang kamu telah mereka-reka yang jahat terhadap aku, tetapi Allah telah mereka-rekanya untuk kebaikan, dengan maksud melakukan seperti yang terjadi sekarang ini, yakni memelihara hidup suatu bangsa yang besar. Jadi, janganlah takut, aku akan menanggung makananmu dan makanan anakanakmu juga." Demikianlah ia menghiburkan mereka dan menenangkan hati mereka dengan perkataannya." Dari ayat ini dapat dilihat kualitas kepemimpinan Yusuf di mana dia tidak pernah menaruh dendam kepada saudara-saudaranya yang pernah menjualnya. Malah sebaliknya, dia mengampuni mereka dan mengatakan itu semua dalam rencana Allah.

Pemimpin Kristen yang sejati harus berpegang teguh pada visinya dan visinya harus berasal dari Allah. Kemudian pemimpin Kristen bukan saja punya visi yang jelas, tetapi yang membuat visinya berbeda dari pemimpin sekuler adalah bahwa dia harus menjadi pemimpin yang berkarakter baik. Apa gunanya memiliki visi yang jelas, tetapi karakternya bobrok, gampang tergoda untuk melakukan dosa, hidup dalam dendam dan sakit hati, maka sia-sia saja memiliki visi yang jelas. Yusuf menjadi contoh, bagaimana dia berpegang teguh pada visinya yang diberikan Tuhan dan memiliki karater kepemimpinan yang luar biasa.

\section{Membaca Peluang}

Dalam Kejadian 4l:47-49, dikatakan, "Tanah itu mengeluarkan hasil bertumpuktumpuk dalam ketujuh tahun kelimpahan itu, maka Yusuf mengumpulkan segala bahan makanan ketujuh tahun kelimpahan yang ada di tanah Mesir, lalu disimpannya di kotakota; hasil daerah sekitar tiap-tiap kota disimpan di dalam kota itu. Demikianlah Yusuf menimbun gandum seperti pasir di laut, sangat banyak, sehingga orang berhenti menghitungnya, karena memang tidak terhitung.

Yusuf menimbun gandum sebanyak mungkin, dia tahu bahwa ini adalah peluang yang sangat berharga dan sayang bila tidak dimanfaatkan dengan baik. Myron Rush menjelaskan, "Kemampuan membaca peluang merupakan tangga menuju keberhasilan."16 Pemimpin yang bisa membaca peluang akan banyak mengambil keuntungan apabila perubahan datang menghampiri pelayanan kepemimpinannya dan dia siap untuk memdulang banyak keuntungan dari perubahan tersebut.

Inilah yang dilakukan Yusuf pada saat dia mau menghadapi perubahan iklim yang menyebabkan kekeringan yang luar biasa dan melanda seluruh tanah Mesir, Kanaan dan sekitarnya. Kemampuannya membaca peluang membuat dirinya bisa melewati krisis pangan selama tujuh tahun di Mesir. Melalui bencana pangan ini Yusuf dikenal sebagai pemimpin yang sanggup membaca peluang dan berhasil selama karir kepemimpinannya di tanah Mesir.

Dalam kepemimpinan dibutuhkan kepekaan di dalam diri pemimpin. Kepekaan yang dimaksud ialah dalam hal membaca peluang yang ada. Presiden Susilo Bambang Yudoyono mengatakan, "Para pemimpin di daerah harus pandai-pandai membaca tanda perubahan zaman serta jeli memanfaatkan berbagai peluang dalam ekonomi lokal, nasional dan internasional." ${ }^{\text {17 }}$ Pemimpin yang tidak bisa membaca peluang akan mengalami kesulitan di dalam kepemimpinannya. Yusuf memunyai kemampuan yang luar biasa dalam hal membaca peluang. Waktu dia diangkat oleh Firaun untuk menjadi pemimpin atas Mesir, Yusuf menggunakan peluang tersebut untuk membuat sesuatu yang luar biasa dengan mengumpulkan segala bahan makanan selama tujuh tahun.

\section{Sadar Perubahan Akan Terjadi}

Dalam Kejadian 41:1-36, bagian firman Tuhan ini menceritakan tentang mimpi Firaun, inti dari mimpi tersebut ialah bahwa akan terjadi masa kemakmuran selama tujuh tahun dan kelaparan selama tujuh tahun pula, hal ini diketahui dari tafsiran mimpi Firaun yang disingkapkan oleh Yusuf. Hal tersebut benar-benar terjadi tepat seperti yang

\footnotetext{
${ }^{16}$ Myron Rush, Manajemen Prima (Jakarta: Immanuel, TT), 32.

17 Susilo Bambang Yudoyono, "Sukses Indonesi Cermin Sukses Daerah," Diakses 22 Maret 2010;
} tersedia di http://www.detikriau.com/index.php?option=com content\&task=view\&\&id=592\& $\&$ Itemid=2 
dijelaskan oleh Yusuf. Jelas bahwa Yusuf bisa mengartikan mimpi Firaun bukan berdasarkan kemampuannya sendiri, tetapi semua kemapuan tersebut berasal dari Tuhan. Dalam Kejadian 41:16, Yusuf menyahut Firaun, "Bukan sekali-kali aku, melainkan Allah juga yang akan memberitakan kesejahteraan kepada tuanku Firaun."

Melalui mimpi Firaun Yusuf menyadari akan terjadi perubahan besar-besaran khususnya perubahan iklim sehingga menyebabkan kelaparan atas seluruh bumi (Kejadian 4l:57). Dengan kesadaran ini Yusuf berhasil dalam kepemimpinannya di Mesir. Myron Rush mengatakan, "Semakin besar kesadaran terhadap perubahan, semakin berhasil Anda mengelola perubahan tersebut."18

Yusuf mengalami banyak perubahan sejak dari rumah orang tuanya sampai dia menjadi pemimpin, perubahan terus menjadi bagian hidupnya. Susanto mengatakan, "Perubahan itu merupakan perubahan yang berlangsung terus-menerus atau dinamis. Suatu perubahan yang akan menyebabkan perubahan yang berikutnya dan bersifat fungsional, yaitu perubahan-perubahan yang terjadi itu berguna bagi kehidupan individu dan bagi proses belajar berikutnya." ${ }^{19}$

Di sini Yusuf sebagai seorang pemimpin menyadari perubahan yang akan terjadi, dia tidak pura-pura tidak tahu bahwa perubahan sedang terjadi dalam kepemimpinannya. Justru dia sadar bahwa perubahan itu ada. Penting sekali pemimpin menyadari bahwa perubahan itu akan terjadi, dengan menyadari perubahan terjadi seorang pemimpin bisa mengatasi perubahan itu. Bill Hybels menjelaskan, "Seorang pemimpin harus memiliki kesadaran terhadap sesuatu yang sedang terjadi di dunianya." ${ }^{20}$ Penjelasan ini menyatakan bahwa seorang pemimpin seharusnya memunyai kesadaran penuh terhadap perubahan yang sedang terjadi.

\section{Mempersiapkan Diri Menghadapi Perubahan}

Kejadian 41:33-36 menjelaskan, Yusuf mengusulkan kepada Firaun untuk mencari orang yang bijaksana, dan mengangkatnya menjadi kuasa atas Mesir. Lalu mengangkat penilik-penilik untuk memungut seperlima dari hasil tanah Mesir dalam tujuh tahun kelimpahan, sehingga tetap tersedia bahan makanan pada tujuh tahun kekeringan. Dari ayat-ayat ini dapat disimpulkan bahwa Yusuf mempersiapkan segala sesuatu sebelum masuk ke dalam perubahan iklim yang menyebabkan kelaparan yang luar biasa melanda seluruh Mesir dan sekitarnya.

Persiapan menghadapi setiap perubahan tidak selalu sama, karena perubahan memunyai bentuk dan kekuatan yang berbeda-beda. Dalam mempersiapkan diri untuk menghadapi perubahan yang akan terjadi perlu penelitian atau pembelajaran terhadap perubahan itu. Myron Rush menegaskan pula, "Pastikan bahwa Anda, sebagai seorang pemimpin, telah memperhitungkan kekuatan yang terkait dalam suatu perubahan." ${ }^{21}$ Kejadian 41:46, menjelaskan bahwa Yusuf mengelilingi tanah Mesir. Dalam perjalanan kelilingnya ini bukan jalan-jalan tanpa tujuan, tetapi dia sedang mencari tahu sebesar apa kekuatan perubahan krisis pangan selama tujuh tahun setelah masa kelimpahan (Kejadian 41:54).

Myron Rush mengatakan, "Pusatkan perhatian pada hal-hal positif dari perubahan dan persiapkan diri untuk menaklukan perubahan." ${ }^{22}$ Mempersiapkan diri berarti mempelajari situasi perubahan, sehingga pemimpin bisa mengambil banyak keuntungan positif dari perubahan. Persiapan yang dilakukan oleh Yusuf tidak muluk-muluk, tetapi dapat dijangkau dan cukup untuk semua orang yang akan datang membeli makanan kepadanya. Persiapan sangat perlu, dengan adanya persiapan yang matang akan sangat membantu untuk bisa melewati setiap perubahan yang ada, Yusuf sanggup menjadi pemimpin atas negara yang besar dan bisa mendulang banyak keuntungan dari perubahan

\footnotetext{
${ }^{18}$ Myron Rush, Manajemen Prima, (Jakarta: Immanuel, TT), 59.

19 Susanto, "Prinsip Pengertian Belajar," diakses 22 Maret 2010; tersedia di http://www. Menger jakantugas.blogspot.com/2009/06/prinsip-pengertian-belajar.html

${ }^{20}$ Bill Hybels, Kepemimpinan yang Berani (Batam: Gospel Press, 2004), 195.

${ }^{21}$ Myron Rush, Manajemen Prima, (Jakarta: Immanuel, TT), 56.

${ }^{22}$ Ibid.
} 
karena dia mempersiapkan diri dengan baik serta mengukur seberapa besar kekuatan yang dimilikinya.

\section{Memanfaatkan Perubahan}

Kejadian 41: 55-57 mengatakan, "Ketika seluruh negeri Mesir menderita kelaparan, dan rakyat berteriak meminta roti kepada Firaun, berkatalah Firaun kepada semua orang Mesir, "Pergilah kepada Yusuf, perbuatlah apa yang akan dikatakannya kepadamu. "Kelaparan itu merajalela di seluruh bumi. Maka Yusuf membuka segala lumbung dan menjual gandum kepada orang Mesir, sebab makin hebat kelaparan itu di tanah Mesir. Juga dari seluruh bumi datanglah orang ke Mesir untuk membeli gandum dari Yusuf, sebab hebat kelaparan itu di seluruh bumi."

Semua orang dari seluruh bumi datang ke Mesir untuk membeli makanan kepada Yusuf. Fakta ini merupakan bukti Yusuf memanfaatkan perubahan dan mengambil keuntungan dari padanya. Myron Rush juga mengungkapkan apa yang menjadi keuntungan dalam mengelola perubahan, "Agar suatu organisasi bertumbuh menjadi kuat, untuk itu selalu memusatkan perhatian pada pelaksanaan perubahan."23

Kepemimpinan Yusuf mampu memanfaatkan perubahan dan mengambil banyak keuntungan bagi kepemimpinannya. Myron Rush menjelaskan, "Manfaatkan segala kesempatan untuk menciptakan suatu iklim dalam organisasi Anda, karena perubahan memainkan peranan yang sangat penting dalam perkembangan kemampuan memimpin Anda." ${ }^{24}$ Memanfaatkan perubahan berarti mendulang banyak keuntungan dalam kepemimpinan.

Pemimpin gereja seharusnya bersikap seperti Yusuf, memandang perubahan sebagai sarana untuk memperoleh banyak keuntungan, tetapi sayang pemimpin gereja malah menganggap perubahan sebagai musuh yang sangat menakutkan. Pola pikir seperti ini yang menyebabkan kepemimpinan dalam gereja tidak berhasil dan menyebabkan banyak gereja mengalami kemunduran dalam pertumbuhannya. Ini disebabkan pemimpinnya tidak bisa memanfaatkan perubahan sebagai sarana pertumbuhan gereja. Padahal Yusuf sudah memakai konsep ini dalam kepemimpinannya dan menjadi pemimpin yang sukses di tanah Mesir.

\section{Menjadi Pengendali Perubahan}

Kejadian 41:56 mejelaskan bahwa kelaparan merajalela di seluruh bumi. Ini artinya tidak ada yang bisa menolak kelaparan itu, tetapi Yusuf mengendalikan semua perubahan itu. Untuk bisa menjadi pengendali perubahan, Yusuf sudah mempersiapkan sebelum hal itu terjadi dengan cara mengumpulkan segala bahan makanan selama tujuh tahun kelimpahan. Dengan demikian, Yusuf menjadi tokoh kepemimpinan di tanah Mesir yang mampu mengendalikan perubahan.

Untuk menjadi pemimpin yang tidak dipengaruhi oleh perubahan, maka satusatunya cara ialah menjadi pengendali perubahan. Pengaruh yang ada dalam perubahan cukup besar dan bisa membuat kepemimpinan tidak berhasil. Tetapi Yusuf mampu menjadi pemimpin yang menjadi pengendali perubahan. Yakob Tomatala mengatakan, "Dengan mengendalikan perubahan, maka Anda akan berhasil mendatangkan hari besok dan dapat berjalan bersama memasuki masa depan dengan pasti yang berujung kepada sukses." 25 Melalui penjelasan ini, sangat penting bagi seorang pemimpin untuk mengendalikan perubahan. Hal ini sangat menentukan keberhasil kepemimpinan dalam menghadapi perubahan.

\footnotetext{
${ }^{23}$ Ibid, 53 .

${ }^{24}$ Ibid, 60

${ }^{25}$ Yakob Tomatala, Mastering Planning (Jakarta: Leadership Foundation, 2001), 27.
} 
Perubahan boleh saja datang, kapan saja dan di mana saja dan pemimpin sejati harus bisa mengendalikan perubahan. Adji Baroto mengatakan, "Kemampuan untuk menyesuaikan diri dan mengatasi perubahan disebut sebagai kemampuan mengelola perubahan atau management of change." ${ }^{26}$ Dalam hal ini yang sebaiknya dilakukan adalah menerima perubahan secara sadar, menyesuaikan diri terhadap perubahan dan mengendalikan perubahan tersebut dengan melaksanakan langkah-langkah tertentu.

Dalam kisah kepemimpinan Yusuf, dia tahu akan ada masa kelimpahan selama tujuh tahun dan dia tahu juga setelah masa kelimpahan itu akan datang juga masa kelaparan selama tujuh tahun. Dengan mengetahui bahwa hal itu akan terjadi, Yusuf tidak diam saja, tetapi mempersiapkan segala sesuatu untuk menghadapi perubahan krisis makanan itu. Yusuf tahu kelaparan itu disebabkan oleh faktor hukum alam, kalau tidak hujan berarti akan terjadi kekeringan, kalau terjadi kekeringan berarti segala tanaman akan mati dan tidak menghasilkan panen yang baik.

\section{Implementasi Prinsip-Prinsip Kepemiminan Yusuf Dalam Kepemimpinan Gereja Dalam Menghadapi perubahan}

Setelah mengetahui apa yang menjadi prinsip-prinsip kepemimpinan Yusuf yang sudah penulis kemukakan di atas, maka hal yang sangat penting yang penulis sampaikan melalui bagian berikut ini adalah, bagaimana caranya mengimplementasikan prinsipprinsip kepemimpinan tersebut secara relevan di dalam kepemimpinan gereja masa kini.

\section{Fokus pada Visi}

Kejadian 37:5-11, mencatat mimpi Yusuf tentang apa yang akan terjadi di masa yang akan datang tentang masa depannya. Berdasarkan mimpi tersebut Yusuf meneruskan perjalan kehidupan kepemimpinannya. Ada banyak masalah yang mencoba menghalangi, namun Yusuf tetap fokus kepada visi yang telah Tuhan tunjukan kepadanya melalui mimpi, sehingga Kejadian 41 merupakan puncak realisasi dari visi tersebut, di mana Yusuf diangkat menjadi pemimpin dan memunyai kekuasaan atas Mesir.

Yusuf adalah pemimpin yang sejati, di mana dia terus fokus dan berpegang teguh pada visinya sehingga dia menjadi pemimpin yang mampu mengendalikan perubahan. John Maxwell mengatakan, "Yusuf berhasil karena ia fokus pada visi masa remajanya."27 Seorang pemimpin yang mampu mengendalikan perubahan adalah pemimpin yang fokus pada visi. Karena visi adalah kekuatan yang menjadikan seorang pemimpin berhasil di dalam kepemimpinannya. Seorang pemimpin gereja pada masa kini harus tetap fokus pada visi awalnya, dengan demikian dia bisa mengendalikan perubahan.

George Barna mengatakan, "Bila tidak ada visi, orang-orang akan binasa." ${ }^{28}$ Jadi, visi memiliki kekuatan yang sangat besar untuk seorang pemimpin, sehingga dia bisa membawa orang-orang yang dia pimpin untuk mencapai tujuan hidup mereka. Ada pemimpin gereja pada zaman sekarang yang tidak punya visi sehingga menjalankan pelayanannya tanpa arah yang jelas. Waktu perubahan datang dia bingung apa yang harus dilakukan atau pada saat ada masalah dia dengan gampang melarikan diri dari tanggung jawabnya sebagai pemimpin.

\footnotetext{
${ }^{26}$ Adji Baroto, "Management of Change," Ketrampilan yang dibutuhkan dalam menghadapi perubahan disaat krisis diakses 23 Maret 2010; tersedia di http: //www.cakrawara.co.id /index. php? opt ion=com content\&view $=$ article\&eid $=54$ 60.

${ }^{27}$ John Maxwell, 21 Menit Paling Bermakna dalam Hari-Hari Pemimpin Sejati (Batam: Interaksara, 2002),

${ }^{28}$ George Barna, The Power of Vision (Jakarta: Metanoia Publishing, 1992), 146.
} 
Karena tidak punya visi yang jelas, maka kepemimpinannya menjadi terbawa arus perubahan dan membosankan sehingga keluarlah ungkapan dari mulutnya. "Mari kita berubah, kita harus melakukan transformasi bagi jemaat ini." Hal ini menyebabkan kebingungan bagi jemaatnya, karena jemaat bingung apa yang harus berubah dan mau berubah ke arah mana, sehingga jemaat pun akan menjadi kurang bersemangat mengikuti pemimpin seperti ini. Bill Hybels mengatakan, "Visi menciptakan energi yang menggerakkan orang-orang untuk bertindak." ${ }^{29}$ Jadi, setiap pemimpin gereja harus memunyai visi dan tetap fokus pada visinya, sehingga menghasilkan energi kepada pengikutnya dan mereka terus bersemangat untuk mencapai tujuan walaupun ada tantangan jemaat tidak gampang mudur dan putus asa.

Ada juga pemimpin yang punya visi, namun tidak memegang visi itu dengan teguh. Waktu perubahan datang, goyanglah visinya dan terpengaruh dengan keadaan perubahan, sehingga jemaat yang dia pimpin mengalami kebingungan. Misalnya, gereja sudah membuat target yang hendak dicapai dalam pelayanan, namun waktu perubahan datang, fokus pelayanan diubah lagi dan terus begitu setiap ada hal-hal yang dianggapnya baru dan menyebakan tidak ada satu pun tujuannya tercapai. Tetapi Rick Warren mengatakan, "Hidup dengan tujuan adalah satu-satunya cara untuk sungguh-sungguh hidup. Lain dari itu berarti asal hidup." 30 Jadi, seorang pemimpin harus punya tujuan dan fokus yang jelas agar kepemimpinannya menjadi hidup dan penuh kegairahan, sehingga jemaat pun mengalami semangat yang sama untuk terus maju mencapai tujuan.

\section{Membaca Tren Perubahan}

Dalam Kejadian 41:47-49, dijelaskan bahwa Yusuf menimbun gandum sebanyak mungkin. Menimbun gandum merupakan sikap kepemimpinan Yusuf yang sanggup membaca tren perubahan. Yusuf tahu benar bahwa perubahan iklim akan terjadi secara drastis di tanah Mesir bahkan melanda juga di berbagai penjuru bumi lainnya. Kemampuannya membaca tren perubahan membuat kehidupan Mesir dan seluruh bumi terpelihara.

Seorang pemimpin yang sanggup mengendalikan perubahan ialah pemimpin yang memiliki kemampuan untuk membaca tren perubahan yang ada. Perubahan adalah bagian dari kehidupan seorang pemimpin, sehingga sangat perlu untuk membaca setiap perubahan yang sedang terjadi. Pada saat sekarang ini orang sedang mengikuti banyak tren perubahan, kalau pemimpin tidak peka terhadap hal-hal seperti itu, maka dirinya akan menjadi pemimpin yang ketinggalan zaman. Anatomy of the Tren mengatakan, "Kemampuan pemimpin membaca tren perubahan ibarat mercu suar atau senter yang memberikan petunjuk tentang arah di depan." 31 Jadi, kemampuan membaca tren perubahan merupakan alat penunjuk arah masa depan bagi sang pemimpin, dengan kemampuan ini dia akan tahu ke arah mana dia akan membawa pengikutnya.

Kegagalan pemimpin sering terjadi bukan karena dia tidak memiliki intelektual, tetapi kegagalannya ialah kurang peka dalam membaca tren perubahan. Barack Obama mengatakan, "Kemenangannya dalam pemilu Presiden Amerika Serikat adalah berkat kepekaannya dalam membaca peluang perubahan dalam masyarakat Amerika dari politik rasisme menuju perubahan." ${ }^{32}$ Kepekaan membaca tren perubahan sangat dibutuhkan oleh sang pemimpin, demikian juga dengan pemimpin gereja harus bisa membaca tren perubahan. Pada pada zaman sekarang fasilitas sangat mendukung bagi pemimpin untuk tidak tertinggal dengan tren-tren yang ada, misalnya internet, semua informasi bisa

\footnotetext{
${ }^{29}$ Bill Hybels, Kepemimpinan Yang Berani (Batam: Gospel Press, 2004), 53.

${ }^{30}$ Rick Warren, The Purpose Driven Life (Malang:Gandum Mas, 2005), 345.

${ }^{31}$ Anatomy of the Tren, diakses 19 April 2010; tersedia di http://biangpenasaran.blogspot. com/2008/01/anatomy-of-trend.html

${ }^{32}$ Barack Obama dalam Simon Saragih, Ketekunan dan Hati Putih Barack Obama (Jakarta: Kompas, 2009), 148 .
} 
didapat di sana, ada banyak fasilitas lain juga yang bisa menjadi pendukung bagi pemimpin untuk bisa membaca tren perubahan.

Dalam membaca tren perubahan ini, penulis hendak menyampaikan kepada setiap pemimpin gereja supaya jangan ketinggalan terhadap hal-hal yang baru atau yang sedang terjadi di dalam kehidupan manusia saat ini. Sebagai contoh gembala jemaat kadang kala kurang pengetahuan tentang teknologi dibandingkan anak-anak sekolah minggu. Anak sekolah minggu lebih pintar bermain internet dan menggunakan berbagai macam situs jejaring sosial, sementara gembalanya masih gagap teknologi, atau anak sekolah minggu sudah menggunakan laptop dan handphone yang canggih, tetapi gembala belum tahu apaapa tentang hal seperti ini dan ini sering menjadi masalah dalam kepemimpinan. John Maxwell mengatakan, "Seorang pemimpin yang sanggup membaca tren perubahan adalah pemimpin yang memunyai intuisi yang baik, melihat apa yang sedang terjadi sekarang dan ia mengerti ke mana organisasinya menuju masa depan."33

Penulis tidak bermaksud supaya para pemimpin gereja hidup dalam kemewahan, tetapi yang penulis maksud ialah, bagaimana pemimpin gereja tidak buta terhadap trentren perubahan atau minimal memiliki pengetahuan tentang hal-hal yang demikian, karena dengan demikian pemimpin tersebut bisa menjadi pengendali perubahan. Pemimpin gereja harus bisa membaca tren perubahan. Presiden Susilo Bambang Yudoyo mengatakan, "Pemimpin harus bisa memanfaatkan peluang, mengambil resiko dan mengukir sejarah." ${ }^{34}$ Jadi, pemimpin harus bisa membaca setiap peluang dan mengikuti tren. Penulis bermaksud di sini bukan semua tren diikuti, melainkan agar pemimpin tersebut bisa mengimbangi mana tren perubahan yang bisa diikuti dan mana yang tidak, juga untuk pengetahuan pemimpin itu sendiri di mana dia tidak ketinggalan dengan perubahan.

\section{Mempersiapkan Diri}

Kejadian 41-1-36, menceritakan tentang mimpi Firaun. Inti dari mimpi tersebut ialah, bahwa akan terjadi masa kemakmuran selama tujuh tahun dan kelaparan selama tujuh tahun pula. Hal ini diketahui dari mimpi Firaun yang ditafsirkan oleh Yusuf. Jelas, Yusuf menafsirkan mimpi bukan dari dirinya sendiri, tetapi Allah yang menyatakan kepadanya. Dengan mengetahui hal-hal yang akan terjadi ke depan, Yusuf langsung mempersiapkan diri dengan sebaik mungkin dengan menimbun gandum sebanyakbanyaknya pada masa kemakmuran untuk memasuki masa kelaparan pada tujuh tahun berikutnya (Kejadian 41:48-49).

Mempersiapkan diri yang penulis maksudkan di sini ialah bagaimana seorang pemimpin gereja bisa memanajemen pelayanan di gereja dengan sebaik mungkin, karena dengan persiapan yang bagus membuat pemimpin tersebut bisa mengendalikan setiap perubahan yang terjadi. Tanpa persiapan yang matang, maka kepemimpinan bisa gagal pada saat perubahan datang. Persiapan yang perlu pemimpin gereja lakukan dalam pelayanan bisa meliputi pembinaan kualitas terhadap staf pelayan gereja. Dengan memiliki tim kerja yang bagus, maka gereja akan gampang untuk menghadapi perubahan yang datang kapan saja. Fandy Tjiptono dan Anastasia Diana mengatakan, "Pemberdayaan merupakkan kunci utama dalam motivasi dan produktivitas." ${ }^{135}$ Staf yang diberdayakan akan mengahasilkan persiapan yang matang bagi gereja untuk menghadapi perubahan.

Persiapan bisa juga dilakukan dengan menganalisis apa saja perubahan yang bakal terjadi, sehingga gereja tidak kaget dengan perubahan. Persiapan ini dilakukan setiap waktu supaya gereja update terhadap perubahan apa pun yang bisa memengaruhi pertumbuhan gereja. Pemimpin gereja yang selalu mempersiapkan diri dengan baik tidak begitu khawatir akan perubahan yang terjadi, tetapi gereja yang tidak mempersiapkan diri pasti dilindas oleh perubahan.

${ }^{33}$ John Maxwell, 21 Menit Paling Bermakna dalam Hari-Hari Pemimpin Sejati (Batam: Interaksara, 2002),

${ }^{34}$ Susilo Bambang Yudoyono dalam Dino Patti Djalal, Harus Bisa!: Seni Memimpin Ala SBY (Jakarta: R\&W, TT), 25.

${ }^{35}$ Fandy Tjiptono dan Anastasia Diana, Total Quality Management (Yogyakarta: Andi, 2003), 130. 
Pemimpin gereja perlu juga mempersiapkan anggota gereja untuk bisa menerima perubahan sebagai batu loncatan untuk mencapai pertumbuhan gereja secara kualitas dan kuantitas. Jemaat perlu dipersiapkan sehingga mereka bisa menerima perubahan sebagai bagian dari kehidupan bergereja. Kebanyakan kegagalan pemimpin gereja dalam kepemimpinannya karena tidak mempersiapkan jemaat dengan baik untuk menghadapi perubahan. Permasalahan mengapa perubahan dalam jemaat sering ditolak oleh jemaat, karena mereka merasa bahwa hal itu baru bagi mereka dan tidak biasa dilakukan oleh jemaat tersebut sepanjang kehidupan berjemaat. Rick Warren mengatakan, "Pemimpin gereja harus terus-menerus mengomunikasikan apa yang menjadi tujuan gereja." adanya komunikasi yang baik antara pemimpin gereja dan jemaat akan membuat jemaat lebih siap dengan apa yang bakal terjadi, waktu ada perubahan mereka tidak kaget, melainkan dapat mempersiapkan diri untuk menerima atau juga menolak perubahan.

Mempersiapkan diri merupakan tanggung jawab pemimpin gereja. Dengan persiapan yang baik, maka gereja tersebut akan mendulang banyak keuntungan dari setiap perubahan yang datang. Tugas mempersiapkan diri ini tidak bisa dilakukan secara instan, tetapi perlu dilakukan secara berkala, sehingga mendapatkan hasil yang maksimal. Rick Warren mengatakan, "Pemimpin gereja berkewajiban membangun dan mempersiapkan pembinaan untuk mencapai kedewasaan rohani jemaat." ${ }^{\text {"37 }}$ Anggota jemaat yang dewasa akan siap sedia dan tetap berpikiran positif pada saat perubahan datang ke dalam gereja. Jemaat yang siap mengahdapi perubahan akan membuat pemimpin gereja berhasil.

\section{Mengendalikan Perubahan}

Kejadian 41:54-57, menceritakan bagaimana sikap Yusuf terhadap perubahan yang terjadi, sedikit pun dia tidak terpengaruh dengan situasi tersebut. Waktu dia tahu akan adanya perubahan iklim yang sangat signifikan sehingga menyebabkan kelaparan bagi seluruh bumi, Yusuf tidak panik dengan hal ini. Justru Yusuf membuktikan diri sebagai pemimpin yang sanggup mengendalikan perubahan, Kejadian 41:56-57 menjelaskan orangorang dari seluruh bumi datang untuk membeli gandum kepadanya.

Mengendalikan perubahan bukan sebuah pekerjaan sampingan pemimpin gereja, tetapi mutlak harus dilakukan oleh pemimpin gereja dalam menghadapi perubahan yang terus melanda gereja saat ini. Perubahan tidak bisa dihindari, melainkan dihadapai sebagai sebuah kenyataan dan bagian dari kehidupan pemimpin gereja. Kemampuan mengendalikan perubahan merupakan seni dari kepemimpinan, karena setiap hari kehidupan pemimpin gereja terus berhadapan dengan perubahan demi perubahan. Robby I. Chandra mengatakan, "Seorang pemimpin terlahir untuk memelihara, menguasai dan mendalikan." ${ }^{38}$ Jadi, tugas seorang pemimpin gereja jelas untuk menjadi mengendali apa pun yang sedang terjadi agar orang yang dipimpinnya tidak terbawa arus perubahan.

Dalam dunia ini tidak ada satu pun yang baku, semua bisa berubah seiring berjalannya waktu, demikian juga gereja. Setiap waktu gereja pun terus berubah mengikuti perkembangan zaman. Mau atau tidak gereja harus menerima kenyataan ini. Itu sebabnya pemimpin gereja harus bisa mengendalikan perubahan. Kalau dia bisa menjandi pengendali perubahan, maka tidak ada satu pun perubahan yang melanda gereja menjadi kendala dalam kepemimpinnya. Ada beberapa hal yang harus dilakukan untuk bisa mengendalikan perubahan yaitu:

\footnotetext{
${ }^{36}$ Rick Warren, The Purpose Driven Church (Malang: Gandum Mas, 2006), 118.

${ }^{37}$ Ibid, 366.

${ }^{38}$ Robby I. Chandra, Transformasi: Dari Kepompong Ke Langit Biru (Bekasi: Binawarga, 2000), 12.
} 


\section{Mencari Indikator Perubahan}

Mengendalikan perubahan bukan sebuah pekerjaan yang gampang, tetapi pekerjaan yang harus dipelajari oleh sang pemimpin. Sama seperti Yusuf, dia bisa menjadi pengendali perubahan, bukan gampang seperti yang tercatat dalam Alkitab, tetapi itu terjadi karena Yusuf selalu belajar dari pengalaman hidupnya. Dia juga mencari apa yang menjadi indikator perubahan tersebut. John Maxwell mengatakan, "Pemimpin sejati selalu mencari tahu jalan mana yang harus ditempuhnya agar dia mencapai kemenangan." ${ }^{39}$ Demikian dengan pemimpin gereja agar bisa mengendalikan perubahan dan tetap menjadi pemenang dalam situasi perubahan apa pun harus mencari indikator perubahan tersebut. Kalau indikatornya sudah ditemukan, maka akan gampang untuk mengendalikan perubahan.

Pemimpin gereja gagal di tahap ini, mereka tahu bahwa perubahan akan terjadi dan sedang terjadi, tetapi tidak mencari tahu apa yang menjadi indikator perubahan itu. Perlu bagi pemimpin tahu apa yang menjadi indikator dari setiap perubahan. Pemimpin gereja sering mengajak anggota jemaatnya untuk berubah atau mengikuti tren perubahan, tetapi yang menjadi persoalan harus berubah ke arah mana, apakah pemimpin tersebut tahu apa yang harus berubah dan apa yang tidak harus diubah. Kesalahan seperti ini yang membuat konsep orang tentang perubahan menjadi negatif.

Mencari indikator perubahan merupakan poin penting yang tidak bisa diabaikan oleh pemimpin gereja, dengan mengetahuinya pemimpin akan gampang untuk mengarahkan ke mana jemaatnya dibawa berubah dan harus mengikuti perubahan yang mana. Walaupun ada banyak perubahan, tetapi tidak semua perubahan harus diikuti, tetapi pemimpin harus jeli melihat perubahan apa yang bisa membawa dampak positif bagi gereja yang pimpinnya.

\section{Mencari Dampak Positif}

Kejadian 4l:46, menjelaskan bahwa Yusuf mengelilingi tanah Mesir, untuk melihat apa yang akan dihasilkan dalam tahun kelimpahan. Pemimpin gereja perlu mempelajari dan mengamati dengan saksama gerak-gerik perubahan, untuk mencari tahu apa dampak positif yang disebabkan perubahan. Penulis di sini bermaksud supaya pemimpin gereja melihat apa saja keuntungannya dari perubahan yang sedang terjadi. Presiden Susilo Bambang Yudoyono menjelaskan, "Di dalam perubahan selalu ada energi positif yang akan membuat kepemimpinan sehat dan produktif." ${ }^{40}$ Jadi, seorang pemimpin harus jeli memandang perubahan, kalau ada dampak positif harus cepat menangkap kesepatan tersebut, sehingga tidak terbuang dengan percuma.

Setiap perubahan harus ditinjau dan diteliti dengan saksama oleh pemimpin gereja, apa ada dampak positifnya bagi pertumbuhan gereja yang sedang dilayaninya. Kalau ada, maka besar kemungkinan bahwa perubahan itu bisa dimanfaatkan untuk menunjang pertumbuhan gereja. Misalanya, fonomena gereja saat ini yang menggunakan full band dalam gereja dan membuat suasana ibadah lebih indah dan harmonis dengan musik moderen, apakah perlu gerejanya mengikuti tren tersebut atau masih relevan mengikuti pola yang tradisional.

Hal seperti inilah yang perlu dicari tahu, kalau memang hal itu membawa keuntungan bagi kepemimpinan gereja dan membawa pertumbuhan bagi iman jemaatnya dan jumlah secara kuantitas bertambah, kenapa tidak mengikuti tren tersebut. Pemimpin gagal karena hal yang positif tidak diikuti, karena mempertahankan hal-hal yang sebenarnya tidak esensial. Pemimpin lebih mempertahankan egonya sendiri, dengan mengabaikan setiap perubahan yang terjadi di sekitarnya dan menganggap seolah-olah tidak ada yang berubah. Presiden Susilo Bambang Yudoyono menjelaskan, "Tugas pemimpin adalah untuk mencari energi positif dari perubahan." ${ }^{41}$ Jadi, pemimpin yang sejati bisa melihat hal ini, sehingga bisa menjadi pengendali perubahan.

\footnotetext{
${ }^{39}$ John Maxwell, 21 Menit Paling Bermakna dalam Hari-Hari Pemimpin Sejati (Batam: Interaksara, 2002), 


\section{Mencari Dampak Negatif}

Pemimpin yang bisa mengendalikan perubahan tidak cukup mencari dampak positifnya saja dari perubahan, tetapi penting juga baginya untuk mencari apa dampak negatifnya kalau perubahan tersebut diikuti. Pemimpin gereja harus melihat dari berbagai segi dari perubahan, tidak bisa melihat dari satu sudut pandang saja, perubahan harus dilihat secara komprihensif, sehingga tidak terjadi kekeliruan dalam menilai serta mengikuti perubahan yang sedang terjadi. Presiden Susilo Bambang Yudoyono mengatakan, "Dalam perubahan juga selalu ada energi negatif terhadap kepemimpinan." ${ }^{42}$ Jadi, bukan saja hal positif yang bisa dibawa oleh perubahan, tetapi ada hal negatifnya juga.

Mencari dampak negatif perubahan, bukan untuk mencari kesalahan perubahan itu sehingga ada alasan bagi pemimpin untuk tidak mau berubah dan mengatakan bahwa perubahan akan membawa dampak negatif bagi pertumbuhan gereja. Penulis tidak bermaksud demikian, tetapi yang penulis hendak sampaikan melalui bagian ini ialah bagaimana pemimpin gereja memandang perubahan dari keseluruhannya tanpa mengabaikan sisi yang lain. Misalnya, kembali ke contoh di atas kalau menggunakan full band dalam gereja berdampak negatif, misalnya jemaat tidak bertumbuh secara iman dan jumlah makin berkurang untuk apa itu dibuat dalam gereja.

Pemimpin gereja sering tidak melihat sisi negatif perubahan, yang mereka lihat hanya sisi positifnya, sehingga yang bukan kebutuhan jemaat pun dimasukkan ke dalam gereja dan dipaksakkan untuk jemaat mengikutinya. Untuk menjadi pemimpin yang mengendalikan perubahan harus bisa melihat perubahan dari keseluruhannya, dengan mencari tahu apa dampak positif dan negatifnya.

\section{Mempersiapkan Sarana}

Kejadian 4l:48-49, mencatat bahwa Yusuf menimbun gandum sebanyak-banyaknya. Ini merupakan cara Yusuf menyiapkan sarana, agar bisa mengendalikan perubahan. Yusuf mempersiapkan apa yang dibutuhkan untuk menghadapi krisis pangan. Yusuf tahu untuk bisa mengendalikan perubahan, tidak cukup hanya mencari indikator perubahan, mencari dampak positif atau negatif perubahan, tetapi perlu juga mempersiapkan sarana perubahan.

Berbicara tentang mengendalikan perubahan itu bukan hanya pemimpin gereja yang melakukannya, tetapi setiap orang dalam jemaat bertanggung jawab dengan tugasnya masing-masing yang sudah ditetapkan oleh pemimpin gerejanya. Penulis bermaksud mempersiapkan sarana di sini ialah bagaimana pemimpin gereja mempersiapkan sarana yang akan dipakai untuk mengendalikan perubahan. Ada pemimpin yang memiliki ide yang cemerlang untuk mengendalikan perubahan, tetapi sarana yang mau dipakai tidak ada, ini menjadi masalah.

Fandy Tjiptono dan Anastasia Diana mengatakan, "Menyediakan sarana untuk menghadapi perubahan, meliputi melatih staf karyawan dan seluruh sarana yang dibutuhkan." ${ }^{43}$ Jadi, mempersiapkan sarana bisa juga dengan cara melatih staf gembala, badan pengurus jemaat, semua pengurus organ dalam pelayanan gereja bahkan anggota jemaat sangat perlu mendapatkan pembekalan sebagai agen pengendali perubahan. Selain itu, juga dibutuhkan pasilitas-pasilitas, misalnya kalau butuh laptop, proyektor dan sarana yang lain-lain ini perlu dipersiapkan dengan baik. Contoh, kalau gereja mau berubah dari gereja yang tradisional ke gereja yang lebih moderen, tetapi sarana untuk mencapai itu tidak ada, maka semuanya hanya mimpi. Jadi, sebelum mejadi pengendali perubahan, maka perlu juga mempersiapkan sarana.

Sarana di sini bukan berbicara tentang kemewahan yang gereja harus miliki, tetapi apa yang dibutuhkan pada saat mau nengendalikan perubahan. Sarana sangat dibutuhkan dalam perubahan, tanpa mempersiapkan sarana dengan baik pemimpin gereja hanya bisa bicara tentang perubahan. Pemimpin akan gagal untuk mengendalikan perubahan kalau mempersiapkan sarana ini diabaikan. Selama ini ada gereja yang mencoba mengikuti tern

\footnotetext{
${ }^{42}$ Ibid, 119.

${ }^{43}$ Fandy Tjiptono dan Anastasia Diana, Total Quality Management (Yogyakarta: Andi, 2003), 131.
} 
perubahan, tetapi gagal mengendalikan perubahan karena tidak ada sarana yang dipersiapkan sebelum masuk ke dalam perubahan.

\section{Menciptakan Perubahan}

Kejadian 4l:46-49 merupakan catatan Alkitab di mana Yusuf menciptakan perubahan, dengan mengumpulkan gandum sebanyak-banyaknya dalam tahun kelimpahan selama tujuh tahun. Orang Mesir pada waktu itu tidak pernah berpikir untuk menyimpan gandum pada masa kelimpahan, tetapi Yusuf adalah seorang pemimpin yang menciptakan perubahan baru dengan mengumpulkan gandum sebanyak-banyaknya pada tahun kelimpahan.

Pemimpin gereja yang sanggup menjadi pengendali perubahan seperti Yusuf, tidak cukup hanya menunggu perubahan itu datang menghampirinya. Tetapi pemimpin yang sejati adalah pemimpin yang aktif menciptakan perubahan demi perubahan tanpa dipengaruhi oleh perubahan yang disebabkan orang lain. Pemimpin gereja tidak boleh puas dengan apa yang ada sekarang, tetapi terus membuat perubahan-perubahan dalam pelayanannya. Untuk menciptakan perubahan, tentu harus dilakukan penelitian sebelumnya. Perubahan yang diciptakan pun tentu perubahan yang positif yang memyebabkan jemaatnya bertumbuh secara kualitas dan kuantitas.

Sebagai contoh, pemimpin gereja bisa membuat perubahan dalam tata ibadah, di mana suasana ibadah tersebut menyajikan sesuatu yang berbeda yang tidak bisa di dapat di tempat lain. Dampaknya ialah gereja tersebut dihadiri banyak orang. Bisa juga menciptakan perubahan dalam manajemen gereja, sehingga orang lain tertarik untuk mempelajari manajemen gereja tersebut. Jadi, perubahan positif harus diciptakan oleh pemimpin gereja secara terus-menerus.

Rick Warren mengatakan, "Pelayanan kepemimpinan bagaikan lari maraton yang penting bukanlah bagaimana Anda memulainya, tetapi bagaimana Anda mengakhirinya." ${ }^{44}$ Jadi, seorang pemimpin tidak boleh hanya puas dengan apa yang dimulainya, tetapi terusmenerus berada dalam persaingan yang ketat dan harus mengakhiri pelayanannya dengan kemenangan.

Perubahan yang diciptakan oleh pemimpin gereja, bisa bervariasi dampaknya, ada yang berdampak lokal artinya hanya berpengaruh di lingkungan gereja di mana dia melayani atau berdampak pada organisasinya saja. Bisa juga berdampak nasional di mana perubahannya memengaruhi seluruh negaranya dan organisasi gereja yang lain. Sedangkan dampak yang lain ialah berdampak internasional, ini dampaknya sangat luas karena berdampak di gereja negara-negara lain.

Dengan terciptanya perubahan seperti ini, maka secara otomatis pemimpin tersebut dapat mengendalikan perubahan yang datang. Kenapa ini bisa terjadi? Karena orang lain sibuk mengatasi perubahan yang diciptakan pemimpin gereja tersebut. Kepemimpinan gereja yang aktif menciptakan perubahan adalah pemimpin yang bisa mengendalikan perubahan dan tidak akan digilas oleh perubahan. Rick Warren mengatakan, "Pemimpin gereja tidak akan digilas oleh perubahan bila mampu menawarkan sesuatu yang orang lain tidak dapati di tempat lain." ${ }^{45}$ Jadi, pemimpin gereja harus berusaha menyajikan sesuatu yang berbeda di gerejanya dengan menciptakan berbagai perubahan yang berdampak positif sehingga menarik minat orang lain.

Dalam bagian ini penulis hendak menyampaikan bahwa mengendalikan perubahan adalah tugas pemimpin gereja pada abad ini, karena tantangan pelayanan gereja semakin berat di mana persaingan dalam mengemas pelayan gereja sangat luar biasa. Itu sebabnya zaman sekarang ini pemimpin yang tidak bisa mengendalikan perubahan akan menjadi korban dari perubahan yang dibuat oleh pemimpin lain. Pemimpin yang bisa bertahan dan tetap eksis dalam tantangan globalisasi ini ialah pemimpin yang aktif menciptakan perubahan demi perubahan.

Kesimpulan dari implementasi prinsip-prinsip kepemimpinan Yusuf dalam kepemimpinan gereja dalam mengahadapi perubahan, penulis hanya membatasinya bagaimana pemimpin gereja bisa menjadi pengendali perubahan yang terjadi dalam

\footnotetext{
${ }^{44}$ Rick Warren, The Purpose Driven Church (Malang: Gandum Mas, 2006), 30.

${ }^{45}$ Ibid, 55.
} 
kehidupan gereja saat ini. Perubahan yang di luar gereja tidak menjadi pokok pembahasan dalam bab ini. Penulis hanya mengungkapkan bagaimana pemimpin gereja masa kini bisa mengendalikan perubahan dalam gereja dengan menggunakan prinsip-prinsip kepemimpinan Yusuf dalam mengendalikan perubahan krisis pangan di tanah Mesir, di mana Yusuf berhasil menjadi tokoh yang mengendalikan perubahan.

\section{PENUTUP}

Dalam bab terakhir ini penulis akan mengungkapkan dua bagian, yaitu, kesimpulan dari seluruh pembahasan dalam karya ilmiah ini dan beberapa saran dari penulis kepada setiap pembaca.

\section{Kesimpulan}

Pertama, Prinsip-prinsip kepemimpinan Yusuf dalam menghadapi perubahan adalah sebagai berikut, (1) Berpegang teguh pada visi yang berasal dari Allah yang ditunjang dengan karakter yang baik, (2) Membaca peluang yang ada, (3) Menyadari perubahan yang akan terjadi, (4) Mempersiapkan diri dalam menghadapi perubahan, (5) Tahu memanfaatkan perubahan yang terjadi, (6) Bisa menjadi pengendali perubahan.

Kedua, Implementasi prinsip-prinsip kepemimpinan Yusuf dalam kepemimpinan gereja masa kini dalam menghadapi perubahan adalah sebagai berikut, (l) Fokus pada visi, (2) Membaca tren perubahan, (3) Mempersiapkan diri, (4) Mengendalikan perubahan dengan cara (a) Mencari indikator perubahan, (b) Mencari dampak positif, (c) Mencari dampak negative, (d) mempersiapkan sarana (5) Menciptakan perubahan.

\section{Saran-Saran}

Agar tujuan penulisan karya ilmiah ini tercapai dan bermanfaat bagi pembaca, maka penulis menyampaikan beberapa saran. Kiranya saran-saran ini dapat memberikan inspirasi bagi para pemimpin gereja yang sedang menghadapi situasi perubahan.

Pertama, Sebagai pemimpin gereja yang hidup pada zaman yang serba mederen yang penuh dengan perubahan, jangan terpengaruh dengan situasi perubahan, melainkan tetap fokus pada visi.

Kedua, Perubahan akan selalu ada dan tidak ada yang dapat menahannya, tetapi pemimpin gereja sejati tidak perlu takut dengan perubahan, karena dalam perubahan selalu ada manfaat yang bisa diambil menjadi sarana untuk menunjang pertumbuhan gereja. Karena itu pemimpin gereja harus jeli melihat situasi perubahan dan ambil setiap manfaat dari perubahan tersebut.

Ketiga, Pemimpin gereja harus mempersiapkan diri sebaik mungkin dalam menghadapi perubahan. Untuk itu, cari indikator perubahannya, temukan apa dampak positif dan negatifnya bagi gereja. Kalau banyak dampak positifnya manfaatkan perubahan tersebut, tetapi kalau negatifnya lebih banyak abaikan saja perubahan itu.

Keempat, Dalam dunia kepemimpin tidak ada sesuatu yang baku, semua bisa berubah, itu sebabanya perlu bagi seorang pemimpin untuk memiliki kemampuan membaca tren perubahan, sehingga bisa memanfaatkan perubahan dan mendulang banyak keuntungan dari perubahan tersebut.

Kelima, Untuk bisa tetap eksis dalam situasi perubahan dan persaingan yang sangat kompetitif, pemimpin sejati harus selalu menciptakan perubahan baru. Jangan menjadi pemimpin yang pasif.

\section{KEPUSTAKAAN}

\section{Alkitab}

Alkitab. Lembaga Alkitab Indonesia, 2006

Alkitab Penuntun Hidup Berkelimpahan. Malang: Gandum Mas, 2008. 


\section{Kamus}

Kamus Besar Bahasa Indonesia. Jakarta: Balai Pustaka, 2001.

Kamus Umum Bahasa Indonesia. Jakarta: Pustaka Sinar, 1994.

\section{Buku-Buku}

Bakker, Anton. dan Achmad Charri Zubair, Metode Penelitian Filsafat. Yogyakarta: Kanasius, 1990.

Barna, George. The Power of Vision. Jakarta: Metanoia Publishing, 1992.

Chandra, Robby I. Kamu Juga Bisa. Jakarta: YLI, 2009. Transformasi: Dari Kepompong ke Langit Biru. Bekasi: Binawarga, 2000.

Darmaputra, Eka. Kepemimpinan dalam Persefektif Alkitab. Yogyakarta: Kairos, 2005.

Djalal, Dino Patti. Harus Bisa!: Seni Memimpin Ala SBY. Jakarta: R\&W, TT.

Engstrom, Ted W. dan Edward R. Dayton. Seni Manjemen Pemimpin Kristen. Bandung: Kalam Hidup, 2007.

Henry dan Blackaby, Richard. Kepemimpinan Rohani. Batam: Gospel Pres, 2005.

Herlianto. Pelayanan Perkotaan: Tanggung Jawab Setiap Umat Kristen. Bandung: Yabina, 1999.

Hybels, Bill. Kepemimpinan yang Berani. Batam: Gospel Press, 2004.

J. Donal Walters, Seni Memimpin Suportif. Jakarta: PT. Gramedia, 2002.

J. Oswald Sander. Kepemimpinan Rohani. Bandung: Kalam Hidup, 2001.

Mangunhardjana, A. M. Kepemimpinan. Yogyakarta: Kanesisus, 1990.

Maxwell, John. 21 Menit Paling Bermakna dalam Hari-Hari Pemimpin Sejati. Batam: Interaksara, 2002.

Munroe, Myles. The Spirit of Leadershi. Jakarta: Immanuel, 2006.

Rice, Howard. Manajemen Umat: Pendeta Sebagai Pengayom, Pemimpin, dan Pembina. Bandung: Kalam Hidup, 2006.

Rush, Myron. Manajemen Prima. Jakarta: Immanuel, TT.

Saragih, Simon. Ketekunan dan Hati Putih Barack Obama. Jakarta: Kompas, 2009.

Schultz, Samuel J. Pengantar Perjanjian Lama: Taurat dan Sejarah. Malang: Gandum Mas, TT.

Siagian, Sondang P. Teori dan Praktek Kepemimpinan. Jakarta:Rineka Cipta, 1991.

Subagyo, Andreas B. Pengantar Riset Kuantitatif dan Kualitatif. Bandung: Kalam Hidup, 2004.

Surakhman, Winarno. Penelitian Ilmiah: Dasar Penelitian Ilmiah. Bandung: Tarsito, 1982. Suryabrata, Sumadi. Metodologi Penelitian. Jakarta: Rajawali Pers, 1991.

Tjiptono, Fandy dan Anastasia Diana. Total Quality Management. Yogyakarta: Andi, 2003.

Tomatala,Yakob. Kepemimpinan Kristen: Mencari Format Kepemimpinan Gereja yang Kontekstual di Indonesia. Jakarta: YT Leadership Foundation, 2001. . Mastering Planning. Jakarta: Leadership Foundation, 2001

Park, Yune Sun. Tafsiran Kitab Kejadian. Batu Malang: YPPI, 2002.

Wagner, C. Peter. Gempa Gereja. Jakarta: Nafiri Gabriel, 2000.

Warren, Rick. The Purpose Driven Church. Malang: Gandum Mas, 2006. . The Purpose Driven Life. Malang:Gandum Mas, 2005.

\section{Bahan Internet}

Anatomy of the Tren, diakses 19 April 2010; tersedia di http://biangpenasaran.blogspot. com/2008/01/anatomy-of-trend.html. 
Andri, Aulia. "Dari Jakarta Menuju Gedung Putih," diakses tanggal 17 Maret 2010: tersedia di_http://komunikasipublik.multiply.com/journal/item /114/Resensi Buku Barack_Obama-Dari_Jakarta_Menuju_Gedung_Putih

Baroto, Adji. "Management of Change," Ketrampilan yang dibutuhkan dalam menghadapi perubahan disaat krisis diakses 23 Maret 2010; tersedia di http://www.cakrawara. co.id/index.php?option $=$ com.ontent $\&$ view $=$ article\&id $=54$

Dubey, S.N. "Bentuk Pemerintahan Monarki," diakses tanggal 15 maret 2010; tersedia di http://www.tasarkarsum.blogspot.com/2007/09/bentuk-pemerintahan-monarki.html

Nasa. "I Care About Global Warming's Notes," diakses tanggal 17 Maret 2010; tersedia di http://www.facebook.com/notes/i-care-about-global-warming / fakta-3 - perubahaniklim cuaca-yang-semakin-ekstrim-fact-3-extreme-climate-change/185495931857

Mustafa, Hasan. "Manajemen Perubahan," diakses 20 Maret 2010; tersedia di http"//www. omusu.blogspot.com/

Ronda, Daniel. “Kekuatan Sebuah Visi,” Daniel Ronda Ministries diakses 23 Maret 2010; tersedia di http://danielronda.blogspot.com/2010/01/kekuatan-sebuah-visi-masihingat-visi.html

Soemardjan, Selo. "Pengertian Perubahan sosial," diakses tanggal 17 Maret 2010; tersedia di http://catatan-ips.blogspot.com/2009/10/pengertian-perubahan-sosial.html

Standarisasi,s Blog. "Kasus Bank Century," diakses 23 Maret 2010; tersedia di http:// standardisasi.wordpress.com/2010/03/05/kasus-bank-century/

Susanto. "Prinsip Pengertian Belajar," diakses 22 Maret 2010; tersedia di http://www. mengerjakantugas.blogspot.com/2009/06/prinsip-pengertian-belajar.html

T. J, Parel. "Gilasan Sebuah Perubahan," Inspiration Ministry diakses 15 Februari 2019; tersedia di htt:///www.Artikel/gilasan-sebuah-perubahan.html.

Tempo Interaktif. "Bisnis' diakses 17 Maret 2010; tersedia di http://www. tempointeraktif. com/hg/bisnis/2009/07/28/brk.20090728-189363.id.html

Wikipedia Bahasa Indonesia, Ensiklopedia Bebas, s.v. "Teokrasi," diakses tanggal 20 Maret 2010; tersedia di http://id.wikipedia.org/wiki/Teokrasi.

Yudoyono, Susilo Bambang. "Sukses Indonesi Cermin Sukses Daerah," Diakses 22 Maret 2010; tersedia di http://www.detikriau.com/index.php?option=com content \& task =view \&id=592\& Itemid $=2$ 